\title{
Ks. Czesław Parzyszek SAC, Życie konsekrowane w posoborowym nauczaniu Kościoła Wydawnictwo Księży Pallotynów „Apostolicum”, Ząbki 2007, 797 s.
}

Kościół, jako Lud Boży Nowego Przymierza jest pielgrzymującą wspólnotą zbawczą, która niesie dzieła ewangelizacyjne, tak w przepowiadanym słowie jak i znakach kultu i miłości bliźniego, zatem to kult i caritas. To zwłaszcza pytania o dar sakramentalnej łaski, którą Bóg w Chrystusie szczególnie hojnie obdarowuje. Dzisiaj, jak to wskazywał wielokrotnie Papież Jan Paweł II dzieło to przybiera nowe formy, a zwłaszcza formę nowej ewangelizacji. Zatem zwłaszcza współcześnie szczególnego znaczenia nabiera świadectwo wiary i życia, wychylone ku nadziei, którą $\mathrm{z}$ taką determinacją konsekwentnie zwiastuje papież Benedykt XVI (por. „Spe salvi”). Patrząc na bogactwo dziś, wydaje się, że dzisiejszy świat zdaje się być $\mathrm{w}$ tym względzie szczególnie wrażliwy i wymagający. Nie powinno to do pewnego stopnia absolutnie dziwić.

Mając na względzie eschatologiczną dynamikę życia Kościoła, dostosowującą się do okoliczności miejsca i czasu, szczególne zobowiązania w tym względzie podejmowane są przez różnorodne wspólnoty, które można do pewnego stopnia określić ogólnym terminem, życia konsekrowanego czy apostolskiego. To wielość charyzmatów i dróg ewangelicznych, które wpisują się, na przestrzeni dziejów Kościoła w jego wyjątkowe bogactwo posługi w przepowiadaniu Ewangelii, świadectwu życia chrześcijańskiego i niesionej posłudze miłości dla innych, zwłaszcza potrzebujących i ludzi z marginesu życia.

Problematyce życia konsekrowanego poświęca książkę ks. dr Czesław Parzyszek, długoletni prowincjał Księży Pallotynów oraz przewodniczący Konferencji i Konsulaty Wyższych Przełożonych Zakonów Męskich w Polsce i jednocześnie twórczo zaangażowany $\mathrm{w}$ różne struktury posługi dla życia konsekrowanego. Trzeba tutaj wskazać, że ks. Cz. Parzyszek jest autorem wielu prac poświęconych życiu konsekrowanemu i apostolskiemu oraz duchowości palotyńskiej.

Prezentowaną książkę otwiera obszerny Spis treści (s. 3-9) oraz Wykaz skrótów (s. 11-14) Zostały one podzielone na Dokumenty Vaticanum II, dokumenty papieskie, dokumenty Stolicy Apostolskiej i inne.

Treściowo w rozprawę wprowadza Wstęp (s. 15-30). Zawiera on wszystkie elementy metodologiczne przypisane tej części rozpraw naukowych. $Z$ kolei całość studium podzielono na dwie obszerne części, z te $\mathrm{z}$ kolei rozdziały.

Część pierwsza została zatytułowana: Posoborowa nauka Kościoła o życiu konsekrowanym (s. 31-385). To niezwykle szeroko problematyka i trudna do syntetycznego ujęcia. W pierwszym rozdziale zostały zaprezentowane Zasad- 
nicze dokumenty Kościoła o życiu konsekrowanym (s. 34-78), które ukazano jako dokumenty soborowe i posoborowe. Na te pierwsze składają się konstytucja Lumen gentium i dekret Perfectae caritatis oraz inne odnoszące się do życia konsekrowanego. Natomiast późniejsze to $\mathrm{z}$ końca XX wieku oraz początku trzeciego tysiąclecia.

Nauka Kościoła o życiu konsekrowanym w czasie pontyfikatu Pawła VI to tytuł drugiego rozdziału (s. 79-115). To przede wszystkim przemówienia do osób konsekrowanych. Jeszcze większe znaczenie miały dwa oficjalne dokumenty: motu proprio Ecclesiae Sanctae i adhortacja Evangelica testificatio. Wskazano tutaj na dokumenty kongregacji watykańskiej: dwie instrukcje Renovationis causa oraz Venite seorsum, a także dokument Mutuae Relationes.

Obszerny trzeci rozdział nosi tytuł Nauka Kościoła o życiu konsekrowanym w czasie pontyfikatu Jana Pawła II (s. 116-303). Autor zaprezentował je w układzie chronologicznym rozpoczynając od przemówień z pierwszych lat pontyfikatu, aby następnie przejść do adhortacji Redemptionis donum. Po liście z okazji Roku Maryjnego Litterae encyclicae zaprezentowano wybrane katechezy środowe. Wskazano tutaj m.in. na miejsce życia konsekrowanego w Kościele, budzenie powołań, poszczególne śluby, modlitwę, życie wspólnotowe. Szczególnie ważna była adhortacja Vitae consecrata oraz list Novo millennio ineunte. W oddzielnym bloku tego rozdziału skoncentrowano się na dokumentach kongregacji, które rozpoczyna prezentacja lat osiemdziesiątych z czteroma instrukcjami: $\mathrm{Nel}$ presentare, Optiones evangelicae, Dimensio contemplativa i Potissimum institutioni. Oddzielnie przeanalizowano dalsze dwie instrukcje Congregavit nos in unum Christi amor i Ripartire da Cisto.

Nauczanie Benedykta XVI przybliża przemówienia okazjonalne, encyklikę Deus caritas est $\mathrm{i}$ adhortację Sacramentum caritatis (s. 304-322)

Kolejny rozdział zajmuje się innym rodzajem nauczania: Wizja życia konsekrowanego w spotkaniach Unii Konferencji Wyższych Przełożonych Europy i na Światowym Kongresie Życia Konsekrowanego (s. 323-354). Autor przybliżył XI Zgromadzenie Plenarne Unii Konferencji Wyższych Przełożonych Europy, II Światowy Kongres Życia Konsekrowanego i XII Zebranie Plenarne Unii Konferencji Wyższych Przełożonych Europy.

Ostatni rozdział tej części został zatytułowany: Zadania zawarte $w$ dokumencie „Idziemy naprzód z nadzieją" (s. 355-385). Ukazano kontekst i motywy powstania dokumentu oraz wskazywane zadania „ad intra” i ,ad extra”.

Elementy teologii życia konsekrowanego w świetle posoborowych dokumentów Kościoła to tematyka drugiej części prezentowanego studium (s. 386-725), którą rozpoczynają uwagi: Natura życia konsekrowanego - „drzewo o licznych gałąkach" (s. 388-470). Autor nakreślił najpierw istotne cechy życia konsekrowanego, aby następnie wskazać na Ewangelię, jako podstawowe źródło tego życia. Wskazał tutaj także na różne formy życia konsekrowanego: życie monastyczne, stan 
dziewic poświęconych Bogu, pustelników i dziewice konsekrowane, instytuty kontemplacyjne, apostolskie i świeckie, stowarzyszenia życia apostolskiego i indywidualne formy życia konsekrowanego.

Wskazując w kolejnym rozdziale na Trynitarne korzenie życia konsekrowanego przypomniano najpierw, że jest to dar „a Patre ad Patrem” (s. 471-495). Nie można oczywiście pominąć prawdy „per Filium” i „in Spiritu”. W całości, jak to przypomina autor jawi się trynitarza pieczęć życia konsekrowanego.

Eklezjalny charakter życia konsekrowanego to tematyka kolejnego rozdziału (s. 496-522). Życie konsekrowane jest darem Boga dla Kościoła powszechnego, ale ich szczególna rola ma miejsce w Kościele lokalnym. Z kolei autor wskazuje na różne płaszczyzny współpracy osób konsekrowanych z pasterzami, duchowieństwem, między sobą oraz ze świeckimi.

Kolejny rozdział ukazuje Zasadnicze wymiary życia konsekrowanego (s. 523-593). Autor zalicza do nich w kolejności następujące wymiary: charyzmatyczny, wspólnotowy, apostolski, kontemplacyjny, prorocki, eschatologiczny, sakramentalny, maryjny.

Mając na względzie wieloraką odpowiedzialność osób życia konsekrowanego następnie wskazano na Główne „,areopagi” życia konsekrowanego (s. 594-630). Po uwagach ogólnych najpierw te „ad intra”: troska o życie duchowe i świadectwo świętości oraz budowanie braterskiej wspólnoty. Z kolei zadania „ad extra” to: nowa ewangelizacja, dzieła społeczne, misje zagraniczne, rozwijanie dialogu oraz komunia ze świeckimi.

„Formacja - miejscem kształtowania się duchowości życia konsekrowanego” to tematyka szóstego rozdziału (s. 631-669). Wskazano na potrzebę formacji, która winna mieć określone etapy: przednowicjacki, nowicjacki, profesów czasowych i permanentna. Oddzielnie zwrócono uwagę na dynamikę wierności.

Ostatni rozdział stawia zadanie, podając jednocześnie jeden $\mathrm{z}$ warunków wypełnienia: „Budować przyszłość z twórczą wiernością” (s. 670-725). Autor wraca do nowych „aeropagów” życia konsekrowanego i wskazuje na zjawisko globalizacji, inkulturację, troskę o „sacrum” i nieustanne odczytywanie „znaków czasu”. W drugim bloku tego rozdziału przedstawia propozycje nowego spojrzenia na życie konsekrowane. To przypomnienie, iż oznacza ono radykalizację życia chrześcijańskiego, naśladowanie Chrystusa - „najdoskonalszego konsekrowanego", niezastąpioną rolę niewiast konsekrowanych i ubogacającą duchowość brata zakonnego.

Całość treściową omawianego studium zamyka zakończenie, które jest pewną próbą podsumowania, ale i zarazem nakreślenia pewnych dalszych planów badawczych (s. 726-731). Z kolei zamieszczono bibliografię (s. 732-778) oraz Riassunto (spis treści i streszczenie) (s. 779-787) i Zusammenfassung (spis treści i streszczenie) (s. 788-797). 
Stosunkowo obszerne opracowanie ks. Cz. Parzyszka podejmuje bardzo szeroką problematykę z zakresu życia konsekrowanego oraz apostolskiego, które może przybierać bardzo zróżnicowane formy. Jego bogate i twórcze zestawienie jest interesującą propozycją, która z pewnością, m.in. ze względu na swój syntetyczny charakter zainteresuje różne środowiska, które podążają droga życia konsekrowanego czy apostolskiego. Spotkanie systematyki oraz obiektywizmu ujęcia tematu prowadzi do bardzo klarownych analiz merytorycznych. Zresztą sam autor pisze we wstępie: „Próba całościowego opracowania problemu życia konsekrowanego może posłużyć do podjęcia głębszego studium poszczególnych elementów nauczania posoborowego Kościoła, jak też i przedstawienia współczesnej teologii życia konsekrowanego na uczelniach katolickich, na wydziałach teologicznych uniwersytetów i w wyższych seminariach duchownych" (s. 25).

Można zauważyć, że istnieje współcześnie pilna potrzeba szerszego przekazu o życiu konsekrowanym i apostolskim w zwyczajnym i codziennym posłannictwie Kościoła, które w praktyce odnosi się do każdego przejawu chrześcijańskiego świadectwa. Jest to tak ważny komponent Ludu Bożego Nowego Przymierza, iż winien on być znacznie bardziej widocznym centrum życiowego zatroskania osobowego, a także refleksji teologicznej, co zresztą tak często i bardzo sugestywnie wskazywał Ojciec Święty Jan Paweł II. Jak można łatwo zauważyć w pracy ewangelizacyjnej, ile jest nowych „areopagów” dla osób życia konsekrowanego, gdzie winny być one owocne czy twórcze ze swym świadectwem Ewangelii (por. s. 594-630, 670-700).

Należy, w tym kontekście, zgodzić się z wieloma wątpliwościami jakie nadal towarzyszą terminologii tutaj występującej, zważywszy m.in. że dyscyplina ta stosunkowo niedawno stała się autonomicznym działem nauk teologicznych. Stąd m.in. autor niniejszego studium odpowiedzialnie stwierdza: „do dziś nie jest jasne, jak należy precyzyjnie zdefiniować pojęcie teologia życia konsekrowanego i dlatego proponowane są określenia opisowe. W rozprawie jednak zastosowano pojęcie życia konsekrowanego, nie pominięto jednak podejścia odmiennego. Otwarta jest zatem droga do dalszych poszukiwań" (s. 727).

Szkoda, że Kodeks Prawa Kanonicznego dla Kościołów Zachodnich Jana Pawła II i jego Katechizm Kościoła Katolickiego nie zyskały większego uznania autora i nie zostały potraktowane jako samodzielne znaczące etapy kształtowania się posoborowej nauki Kościoła o życiu konsekrowanym, w tym jego teologii. Zwłaszcza ma się wrażenie, że nie doszła do głosu teologia prawa, która jest także ważnym elementem kompleksowego widzenia wykładni nauczania Kościoła, a zwłaszcza Jana Pawła II. Szkoda także, że zupełnie zabrakło odwołania do Kompendium Katechizmu Kościota Katolickiego i Kompendium Nauki Spotecznej Kościota, choć tam wskazań odnoszących się do poruszanych kwestii jest niewiele, ale są one szczególnie znaczące $\mathrm{w}$ kontekście rangi doktrynalnego przepowiadania. Te dokumenty nauczania powszechnego Kościoła są szczególnie rozpropagowane 
(wiele przekładów językowych) i mają znaczący wpływ na kształtowanie się konkretnych przejawów życia konsekrowanego oraz spojrzenia na nie w Kościele, a w pewnym sensie, np. prawnym i poza Kościołem. W nazewnictwie dokumentów wydawanych przez Stolicę Apostolską istnieją znaczne różnice między występującymi w wykazie skrótów i bibliografii. Jest to istotne ze względu na charakter doktrynalny czy prawny określonego dokumentu.

W prezentowanym studium duże uznanie budzą zgromadzone źródła i bibliografia, które podzielone zostały na Pismo Święte; Dokumenty Kościoła powszechnego, Nauczanie papieży; Dokumenty Stolicy Apostolskiej, Literatura przedmiotu, Literatura pomocnicza. To wymowny i zarazem do pewnego stopnia klasyczny podział w tym względzie, który daje ogólne elementy wprowadzające w tym względzie. Generalnie bibliografia została przygotowana $\mathrm{z}$ dużą pieczołowitością i stanowić może wstępne zestawienie dla ewentualnych dalszych badań w tej problematyce. Jednak znaleźć można w tym względzie pewne braki, nieścisłości czy niekonsekwencje, które jednak nie pomniejszają w niczym generalnych zasad bibliograficznych.

Trzeba stwierdzić, że w przypadku tłumaczeń nie ma jednoznacznej zasady podawania występowania tekstu oryginalnego, jego określenia czy innych odniesień. Wydaje się, że przy wskazaniach tekstów patrystycznych należy precyzyjnie podać źródło. Warto pamiętać, że w tym względzie prawnie powszechnie przyjęte są jasne zasady, które ułatwiają odniesienia i bibliograficzne. Ze szczegółów można wskazać, że dwukrotne przywołanie S. Miecznikowskiego wskazuje, że chodzi o tę samą pozycję (s. 763). Summa Theologica św. Tomasza z Akwinu należało raczej podać jako jedno dzieło, a nie poszczególne jego fragmenty.

Oto polskie środowisko naukowe doczekało się tak obszernego przedstawienia stosunkowo długiego okresu nauczania kościelnego w zakresie życia konsekrowanego, który jednak zasadniczo dotyczy XX wieku. Jednak posoborowe nauczanie w tym względzie jest niezwykle obszerne i bogate, czasem nawet trudne do jednoznacznego rozeznania. Dotyczy to nie tyle ilości osób, co bardziej bogactwa treściowego, tak w płaszczyźnie teologicznej jak i liturgicznej oraz prawno-kanonicznej. Z pewnością opracowanie to może służyć jako pewne kompendium czy klucz wprowadzający w dalsze bardziej szczegółowe badania. 